\title{
Foliar Treatments as a Strategy to Control Iron Chlorosis in Orange Trees
}

\author{
M. Pestana ${ }^{1}$, P.J. Correia ${ }^{1}$, M.G. Miguel ${ }^{1}$, A. de Varennes ${ }^{2}$, J. Abadía ${ }^{3}$ and E. de Araújo \\ Faria $^{1}$ \\ ${ }^{1}$ Universidade do Algarve, FERN, Campus de Gambelas, Portugal \\ ${ }^{2}$ Instituto Superior de Agronomia, DQAA, Tapada da Ajuda, Lisboa - Portugal \\ ${ }^{3}$ Departamento de Nutrición Vegetal, EEAD, CSIC, Zaragoza, Spain
}

Keywords: chlorophill, Citrus, floral analysis, fruit quality, iron

\begin{abstract}
Different foliar treatments were applied to evaluate the recovery of iron chlorosis of orange trees (Citrus sinensis (L.) Osb. cv. 'Valencia late') grown on a calcareous soil. The treatments were: Fe (II) sulphate $\left(500 \mathrm{mg} \mathrm{Fe} \mathrm{L}^{-1}\right)$, sulphuric acid $\left(0.5 \mathrm{mM} \mathrm{H}_{2} \mathrm{SO}_{4}\right)$, Fe (III)-chelate (Hampiron 654 GS, $120 \mathrm{mg} \mathrm{Fe} \mathrm{L}^{-1}$ ) and distilled water as a control. The recovery from iron chlorosis was evaluated with the SPAD502 apparatus and the values converted to total chlorophyll concentration. The effects of treatments on the mineral composition of leaves and flowers, and the size and quality of fruits were evaluated. The residual effect of treatments was also evaluated one year later. In orange trees, the use of frequent foliar sprays with Fe was able to alleviate Fe chlorosis and prevented yield and quality losses caused by Fe chlorosis. Compared with the control, sprays of Fe (II) sulphate led to higher concentrations of chlorophyll, $\mathrm{Fe}$ and $\mathrm{Zn}$ in leaves and flowers at the end of the experimental period, and significantly improved fruit size and quality. Leaf Fe concentration increased after the sulphuric acid spray, but this treatment did not affect fruit quality parameters. The mineral composition of flowers and leaves was correlated with some fruit quality parameters obtained one year later. These results suggest that foliar sprays with Fe could help to avoid fruit quality losses caused by Fe chlorosis in citrus orchards.
\end{abstract}

\section{INTRODUCTION}

Lime induced chlorosis is a nutritional disorder common in fruit tree orchards established on calcareous soils. In these soils, iron availability does not fulfil plant needs in spite of the high total soil Fe concentrations (Chen et al., 1982). Consequently, mineral composition of leaves and flowers is affected (Sanz et al., 1994; Belkhodja et al., 1998) and without $\mathrm{Fe}$ fertilization, losses in fruit yield and quality are observed. The correction of iron chlorosis in trees is normally achieved by the application of Fe (III)-chelates such as Fe-EDDHA to these soils (Mengel, 1995). This practice has to be repeated every year because $\mathrm{Fe}$ is rapidly immobilized (Tagliavini et al., 2000). Tagliavini et al., 2000 rewieved the effects of foliar treatments with different compoundsin fruit trees an calcareous soils. Acidic treatments could also release Fe immobilized within the plant by changing apoplastic $\mathrm{pH}$.

The aim of this work was to evaluate the effectiveness of different foliar applications to alleviate Fe chlorosis in orange trees. The residual effect of treatments was evaluated one year later.

\section{MATERIALS AND METHODS}

Sixteen orange trees (Citrus sinensis L. (Osb.) cv. 'Valencia Late', grafted on Citrus aurantium L.) were selected in an orchard established on a calcareous soil located in southern Portugal. The soil was a Calcic Cambisol (FAO-Unesco, 1985). The four treatments applied by foliar sprays were Fe (II) sulphate $\left(500 \mathrm{mg} \mathrm{Fe} \mathrm{L}^{-1}\right)$, sulphuric acid $\left(0.5 \mathrm{mM} \mathrm{H}_{2} \mathrm{SO}_{4}\right.$ ), Fe (III)-chelate (Fe-EDDHA, Hampiron 654 GS from Rhône-Poulenc, $120 \mathrm{mg} \mathrm{Fe} \mathrm{\textrm {L } ^ { - 1 }}$ ) and distilled water as a control. A non-ionic wetting agent was used in all treatments (Etaldyne, Rhône-Poulenc, $0.5 \mathrm{~mL} \mathrm{~L}^{-1}$ ). The $\mathrm{pH}$ values of these solutions were 
3.4, 2.3, 6.4 and 6.2, respectively. Treatments started on August 1997, and were made every two weeks until March 1998, when the crop was harvested. The treatments were applied a total of 10 times. Sprays were applied to at least four branches per tree, in four trees per treatment. We tested the foliar application of Fe-EDDHA, a synthetic Fe chelate usually applied to soil, since some authors showed that alternative products like Fe-EDTA or Fe-DTPA led only to a partial re-greening or had no effect (Legaz, 1992; Loupassaki et al., 1997). Total leaf chlorophyll (Chl) concentration was determined at the beginning and at the end of the experiment, in the branches selected, using a SPAD-502 apparatus

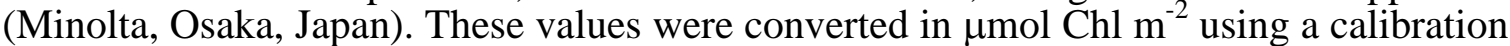
curve previously determined (Pestana et al., 2001). At least 30 flowers and 30 healthy, recently expanded leaves were randomly collected per tree. Mineral composition of flowers and leaves was determined accordingly to Pestana et al. (2001). For fruit quality tests, at least 10 fruits were collected on March 1998, from treated branches on each of the selected trees. Fresh weight, fruit diameter, juice content, total soluble solids concentration, and citric acid concentration were determined (A.O.A.C., 1990). Fruits were again collected to assess the residual effects of treatments on quality parameters one year later. Ascorbic acid was also determined in at least in 5 fruits per treatment by HPLC (Wills et al., 1984). The effects of treatments were evaluated using analysis of variance and the means compared using the Duncan Test at the 95\% significance level (SAS Institute, 1989).

\section{RESULTS}

At the beginning of the experiment all trees showed moderate iron chlorosis with

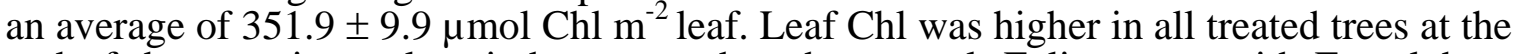
end of the experimental period, compared to the control. Foliar spray with Fe sulphate was the most effective treatment for controlling Fe chlorosis (Fig. 1).

Trees sprayed with Fe sulphate showed the highest concentrations of $\mathrm{Fe}$ and $\mathrm{Zn}$ both in leaves and flowers (Fig. 2) compared with other treatments. The application of sulphuric acid or Fe chelate also led to higher Fe concentrations in the leaves compared with the control. The highest leaf and flower K concentrations occurred in trees treated with $\mathrm{Fe}$ sulphate and in trees sprayed with Fe chelate, respectively. Compared with the control, leaf concentrations of $\mathrm{P}$ and $\mathrm{Mg}$ were higher in trees treated with sulphuric acid and $\mathrm{Fe}$ sulphate or sulphuric acid, respectively. Application of these products did not affect the concentration of $\mathrm{Ca}, \mathrm{Cu}$ and $\mathrm{Mn}$ either in leaves or in flowers (data not shown).

In the first harvest season (1998), the fruits of the trees sprayed with Fe sulphate were larger (diameter), heavier (fresh mass) and matured earlier (maturation index) than those of control or trees treated with sulphuric acid (Table 1). The treatment with Fe sulphate, but not with the chelate, also increased the fruit juice content. Citric acid concentration in fruits from trees sprayed with iron (either as Fe sulphate or Fe chelate) was lower than those of control trees. One year after the application of the treatments, the fruits of control still had smaller diameters, less juice and fresh weight than those from other treatments. The total soluble solids, maturation index and the ascorbic acid content were similar in all fruits independently of treatments (Table 1). Several correlations were found between quality parameters and floral or leaf nutrient concentrations (Table 2). For example, fruit fresh weight was positively related with leaf $\mathrm{P}, \mathrm{K}, \mathrm{Fe}$ and $\mathrm{Zn}$ and flower $\mathrm{Mg}, \mathrm{Fe}$ and $\mathrm{Zn}$.

\section{DISCUSSION}

The increment of Chl due to the acid spray likely depended on the higher Fe activity, possibly due to the decrease of apoplastic $\mathrm{pH}$ (Mengel, 1995) and/or to the effect of sulphur in chlorophyll biosynthesis (Imsande, 1998). A positive response was also obtained with $\mathrm{Fe}$ compounds and, as expected in this case, there was an increment of Fe pools in leaves and flowers. The re-greening of the leaves sprayed with Fe sulphate was possibly related with the increase of $\mathrm{Fe}$ and $\mathrm{Zn}$ in leaves and flowers.

Iron chlorosis was also associated with $\mathrm{P}, \mathrm{Mg}, \mathrm{K}$ and $\mathrm{Zn}$ deficiencies. Together, 
these elements negatively affected fruits characteristics and caused a delay in fruit ripening. The application of $\mathrm{Fe}$ to orange trees led to an increase in fruit quality and advanced ripening. In citrus, harvest is set by the maturation index; at full maturity the acidity (mainly citric acid) declines and the sugar concentration (expressed as total soluble solids) increases. Acidity is a major determinant of fruits taste and edibility. It depends on the concentration of citric acid, probably produced by a side cycle that coexists with the tricarboxylic acid cycle, where iron plays an important role on the activity of aconitase (Spiegel-Roy and Goldschmidt, 1996).

Fruit size and quality did not increase in trees sprayed with sulphuric acid in the first year but in the second this treatment was as effective as those with Fe on fruit size and weight. In the first year the effect of sulphuric acid on apoplastic $\mathrm{pH}$ apparently led to a mobilization of iron in the leaves (since chlorophyll increased), which presumably resulted in enhanced photosynthesis and accumulation of reserves for the growth the following year. It seems that fruit size and quality in year two were mainly dependent on the nutritional status in the previous year, i.e. a delayed effect of sulphuric acid was observed. These results suggest that particular attention should be payed to long term effects, when assessing the efficacy of foliar sprays to correct iron chlorosis.

The results obtained in this experiment show that foliar sprays with Fe can prevent the losses in fruit quality associated with Fe chlorosis. Furthermore, these treatments could be done with relatively cheap materials such as solutions containing Fe (II) sulphate. On the other hand, foliar applications made in 1997-98 had a positive effect on fruit quality one year later. The mineral composition of flowers was sensitive enough to predict fruit quality patterns.

\section{ACKNOWLEDGEMENTS}

This work was supported by AIR3-CT94-1973 and 3/3.2/HORT/2160/95 Projects. We thank N. Correia for the use of the orchard and P. Ferreira for technical assistance.

\section{Literature Cited}

Chen, Y. and Barak, P. 1982. Iron nutrition of plants in calcareous soils. Adv. Agron. $35: 217-240$.

A.O.A.C. 1990. Association of Official Agricultural Chemists. Official Methods of Analysis. $12^{\text {th }}$ ed., Washington, USA.

Belkhodja, R.; Morales, F.; Sanz, M.; Abadía, A. and Abadía, J. 1998. Iron deficiency in peach trees: effects on leaf chlorophyll and nutrient concentrations in flowers and leaves. Plant Soil, 203:257-268.

FAO-Unesco 1985. Soil map of the world. Vol. 5 - Europe. Rome, Italy, 199 p.

Imsande, J. 1998. Iron, sulphur, and chlorophyll deficiencies: A need for an integrative approach in plant physiology. Physiol. Plant., 103:139-144.

Legaz, F.; Serna, M.D.; Primo-Millo, E. and Martin, B. 1992. Leaf spray and soil application of Fe-chelates to Navelina orange trees. Proc. Int. Soc. Citric., 2:613-617.

Loupassaki, M.H.; Lionakis, S.M. and Androulakis, I.I. 1997. Iron deficiency in kiwi and its correction by different methods. Acta Hort., 444:267-271.

Mengel, K. 1995. Iron availability in plant tissues - iron chlorosis on soil calcareous, pp. 389-397, In: J. Abadía (ed.), Iron nutrition in soils and plants. Kluwer Academic Publishers, Dordrecht, Netherlands.

Pestana, M.; Correia, P.J.; Varennes, A. de; Abadía, J. and Faria, E.A. 2001. Effectiveness of different foliar applications to control iron chlorosis in orange trees grown on a calcareous soil. J. Plant Nutr., 24(3):613-622.

Sanz, M.; Pascual, J. and Machín, J. 1997. Prognosis and correction of iron chlorosis in peach trees: Influence on fruit quality. J. Plant Nutr., 20(11):1567-1572.

SAS Institute. 1989. SAS/STAT User's Guide. $6^{\text {th }}$ Version, SAS Institute Inc., Cary, USA.

Spiegel-Roy, P. and Goldschmidt, E.E. (1996). Biology of Citrus, $1^{\text {st }}$ Ed., Cambridge University Press, Cambridge, UK. 
Tagliavini, M.; Abadía, J.; Rombolà, D.; Abadía, A.; Tsipouridis, C. and Marangoni, B. 2000. Agronomic means for the control of iron chlorosis in deciduous fruit plants. J. Plant Nutr., 23(11):2007-2022.

Wills, R.B., Wimalasiri, P. and Greenfield, H. 1984. Dehydroascorbic acid levels in fresh fruit and vegetables in relation to total vitamin C. J. Afric. Food Chem., 32:836-838.

\section{Tables}

Table 1. Effects of foliar applications made during 1997-1998 on the size and quality of oranges collected on March 98 and March 99. Means in a column followed by the same letter are not significantly different at the $95 \%$ probability level (Duncan test).

\begin{tabular}{|c|c|c|c|c|c|c|c|}
\hline \multirow{2}{*}{$\begin{array}{c}\text { Foliar } \\
\text { applications } \\
(1997-98)\end{array}$} & \multicolumn{7}{|c|}{ Fruit harvest (1998) } \\
\hline & $\begin{array}{l}\text { Fresh mass } \\
\left(\mathrm{g}_{\text {fruit }}{ }^{-1}\right)\end{array}$ & $\begin{array}{l}\text { Diameter } \\
(\mathrm{mm})\end{array}$ & $\begin{array}{l}\text { Juice } \\
\text { content } \\
\text { (ml) }\end{array}$ & $\begin{array}{c}\text { Total } \\
\text { soluble } \\
\text { solids } \\
\left({ }^{\circ} \text { Brix }\right) \\
\end{array}$ & $\begin{array}{l}\text { Citric } \\
\text { acid } \\
(\% \mathrm{~m} / \mathrm{v})\end{array}$ & $\begin{array}{l}\text { Maturation } \\
\text { index }\end{array}$ & $\begin{array}{c}\text { Ascorbic } \\
\text { acid } \\
(\% \mathrm{~m} / \mathrm{m})\end{array}$ \\
\hline Control & $184 \mathrm{~b}$ & $72 \mathrm{~b}$ & $89 \mathrm{~b}$ & $10.2 \mathrm{a}$ & $1.2 \mathrm{a}$ & $9.1 \mathrm{~b}$ & - \\
\hline Sulphuric acid & $179 \mathrm{~b}$ & $72 \mathrm{~b}$ & $90 \mathrm{~b}$ & $9.9 \mathrm{a}$ & $1.1 \mathrm{ab}$ & $9.3 \mathrm{~b}$ & - \\
\hline Iron chelate & $193 \mathrm{ab}$ & $74 \mathrm{ab}$ & $94 \mathrm{ab}$ & $10.1 \mathrm{a}$ & $1.0 \mathrm{bc}$ & $10.4 \mathrm{ab}$ & - \\
\hline Iron sulphate & $206 \mathrm{a}$ & $76 \mathrm{a}$ & $\begin{array}{l}98 \mathrm{a} \\
\text { Erui }\end{array}$ & $\begin{array}{c}9.3 \mathrm{a} \\
\text { harvest }\end{array}$ & $\begin{array}{l}0.9 \mathrm{c} \\
1999)\end{array}$ & $10.9 \mathrm{a}$ & - \\
\hline Control & $143 \mathrm{~b}$ & $65 \mathrm{~b}$ & $67 \mathrm{c}$ & $10.2 \mathrm{a}$ & $1.8 \mathrm{a}$ & $5.7 \mathrm{a}$ & $0.033 \mathrm{a}$ \\
\hline Sulphuric acid & $179 \mathrm{a}$ & $71 \mathrm{a}$ & $87 \mathrm{~b}$ & $10.2 \mathrm{a}$ & $1.7 \mathrm{ab}$ & $5.9 \mathrm{a}$ & $0.041 \mathrm{a}$ \\
\hline Iron chelate & $183 \mathrm{a}$ & $71 \mathrm{a}$ & $88 \mathrm{ab}$ & $9.9 \mathrm{a}$ & $1.7 \mathrm{ab}$ & $6.1 \mathrm{a}$ & $0.039 \mathrm{a}$ \\
\hline Iron sulphate & $193 \mathrm{a}$ & $72 \mathrm{a}$ & $95 \mathrm{a}$ & $9.9 \mathrm{a}$ & $1.6 \mathrm{~b}$ & $6.1 \mathrm{a}$ & $0.040 \mathrm{a}$ \\
\hline
\end{tabular}


Table 2. Correlations (r) between nutrient concentrations in flowers and leaves of orange trees (1998) and some fruit quality parameters (1999). Significantly at $\mathrm{p}<0.05\left(^{*}\right)$ or $\mathrm{p}<0.01(* *)$.

\begin{tabular}{|c|c|c|c|c|c|c|}
\hline \multirow{2}{*}{$\begin{array}{c}\text { Nutrients } \\
\text { (1998) }\end{array}$} & \multicolumn{6}{|c|}{ Fruits (1999) } \\
\hline & $\begin{array}{c}\text { Fresh } \\
\text { weight }\end{array}$ & $\begin{array}{l}\text { DIAMETE } \\
\mathrm{R}\end{array}$ & $\begin{array}{c}\text { Juice } \\
\text { content }\end{array}$ & $\begin{array}{c}\text { Total } \\
\text { soluble } \\
\text { solids }\end{array}$ & Citric acid & $\begin{array}{c}\text { Ascorbic } \\
\text { acid }\end{array}$ \\
\hline \multicolumn{7}{|l|}{ Flowers } \\
\hline $\mathrm{P}$ & 0.17 & 0.20 & 0.20 & -0.17 & -0.14 & -0.33 \\
\hline K & 0.12 & 0.12 & 0.03 & -0.14 & -0.30 & -0.08 \\
\hline $\mathrm{Ca}$ & 0.39 & 0.22 & 0.33 & -0.33 & -0.20 & 0.27 \\
\hline $\mathrm{Mg}$ & $0.48^{*}$ & $0.44 *$ & 0.37 & -0.39 & $-0.66 * *$ & 0.23 \\
\hline $\mathrm{Cu}$ & 0.36 & 0.28 & 0.28 & -0.17 & -0.26 & 0.34 \\
\hline Mn & 0.20 & 0.36 & 0.24 & -0.17 & $-0.60 * *$ & -0.43 \\
\hline $\mathrm{Fe}$ & $0.46^{*}$ & 0.40 & $0.47 *$ & -0.22 & $-0.51 *$ & -0.25 \\
\hline $\mathrm{Zn}$ & $0.51 *$ & $0.48 *$ & $0.58 * *$ & $-0.44 *$ & -0.22 & -0.12 \\
\hline \multicolumn{7}{|l|}{ Leaves } \\
\hline $\mathrm{P}$ & $0.57 * *$ & $0.48^{*}$ & $0.56 * *$ & $-0.44^{*}$ & -0.08 & -0.01 \\
\hline K & $0.46^{*}$ & $0.46^{*}$ & $0.46^{*}$ & -0.33 & -0.10 & $-0.47 *$ \\
\hline $\mathrm{Ca}$ & 0.41 & 0.40 & 0.30 & -0.14 & -0.26 & -0.19 \\
\hline $\mathrm{Mg}$ & 0.41 & 0.37 & 0.32 & -0.10 & -0.14 & -0.20 \\
\hline $\mathrm{Cu}$ & 0.33 & 0.30 & 0.24 & -0.17 & $-0.44^{*}$ & 0.16 \\
\hline $\mathrm{Mn}$ & 0.37 & 0.30 & 0.26 & -0.22 & $-0.57 * *$ & -0.23 \\
\hline $\mathrm{Fe}$ & $0.59 * *$ & $0.50 *$ & $0.63 * *$ & -0.40 & -0.36 & -0.18 \\
\hline $\mathrm{Zn}$ & $0.54 * *$ & $0.48^{*}$ & $0.54 * *$ & -0.32 & -0.20 & -0.31 \\
\hline
\end{tabular}

\section{Figures}

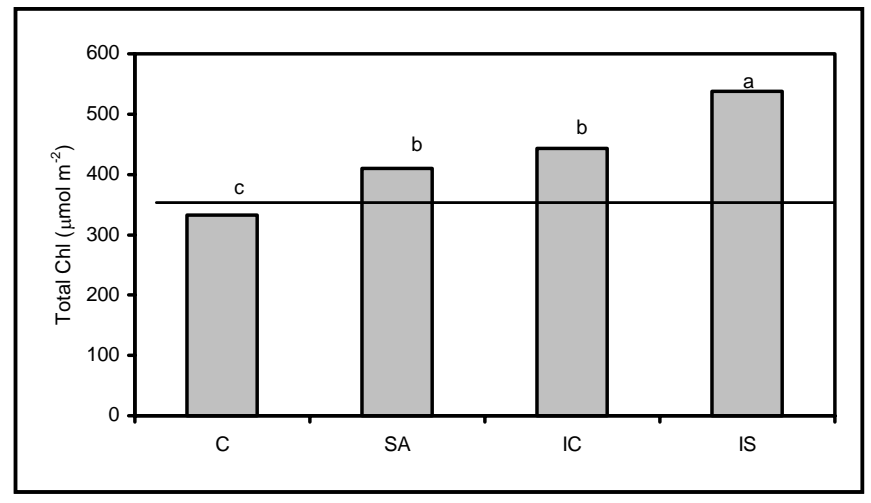

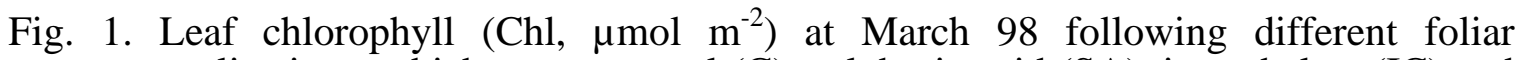
applications, which were: control (C), sulphuric acid (SA), iron chelate (IC) and iron sulphate (IS). The line indicates the average of leaf Chl at the beginning of the assay. For each treatment, means in a column followed by the same letter are not significantly different at the $95 \%$ probability level (Duncan test). 

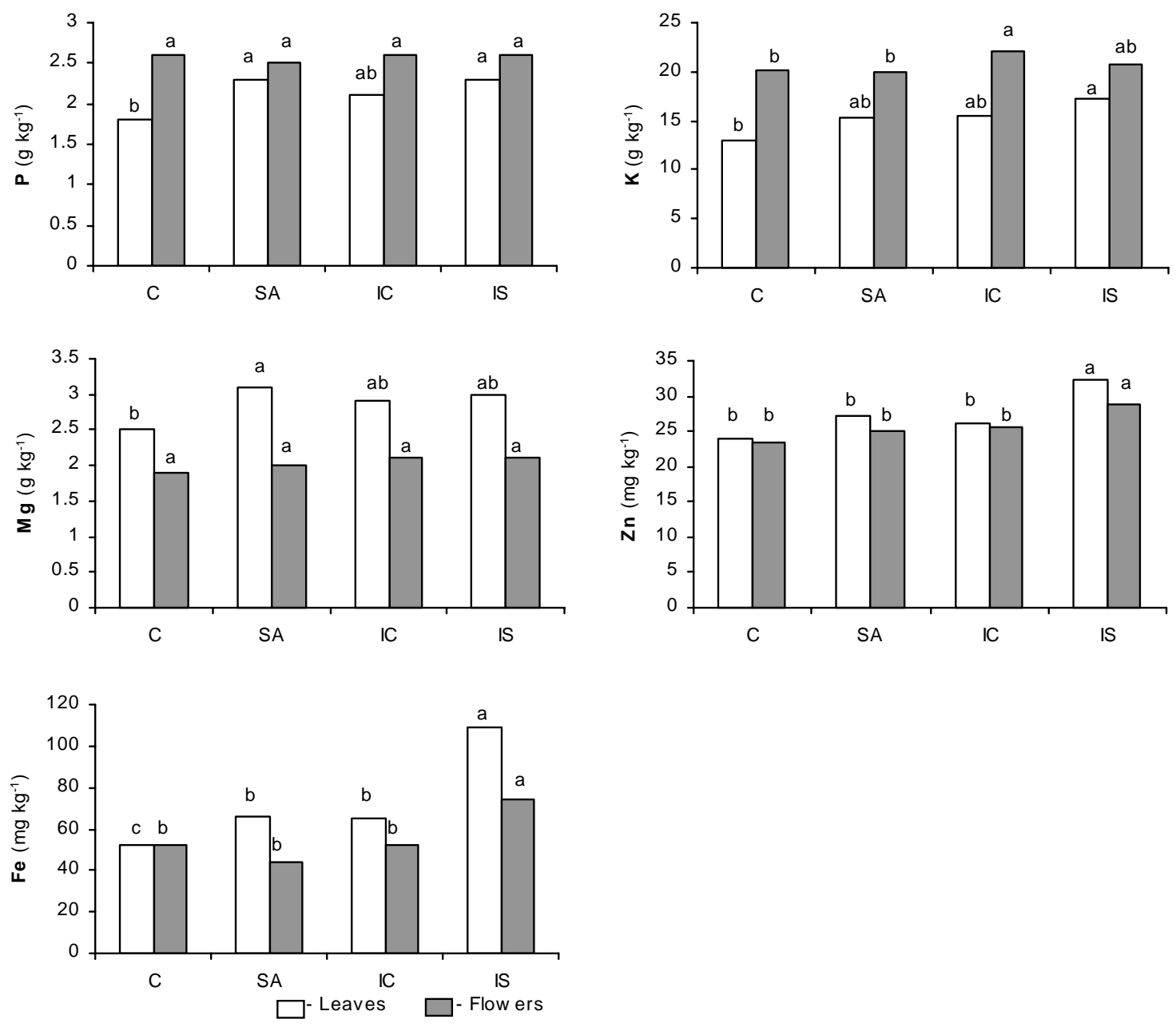

Fig. 2. Mineral composition of leaves and flowers from citrus trees at March 98, following different foliar applications, which were: control (C), sulphuric acid (SA), iron chelate (IC) and iron sulphate (IS). For each nutrient and plant part, means in a column followed by the same letter are not significantly different at the $95 \%$ probability level (Duncan test). 